\title{
Technological Resources Evaluation in the context of the micro-enterprise development
}

\author{
Renata Stasiak-Betlejewska ${ }^{1, *}$, Luminia Parv $^{2}$, and Justyna Karolczyk $^{3}$ \\ ${ }^{1}$ Ing. PhD., Czestochowa University of Technology, Faculty of Management, Department of \\ Production Engineering and Safety, Al. Armii Krajowej 19B, Częstochowa, Poland \\ ${ }^{2}$ Assoc. Prof., Transilvania University of Braşov, Faculty of Technological Engineering and Industrial \\ Management Colina Universitatii, Colina Universitatii nr. 1, corp A, 500036 Brasov, Romania \\ ${ }^{3}$ Student, Czestochowa University of Technology, Faculty of Management, Al. Armii Krajowej 19B, \\ Częstochowa, Poland
}

\begin{abstract}
The object of the paper is technological resources analysis in the context of selection of the micro-enterprise development direction aimed at gaining the product quality improvement. Paper presents results of the study conducted in chosen micro-enterprise of the furniture industry with using $\mathrm{ABC}$ technology method to identify modernity technological level for chosen machine. Presented research results allows identifying technological development direction for the analysed furniture enterprise.
\end{abstract}

\section{Introduction}

The problem of the enterprise development is generally perceived in five characteristic dimensions: economic, organizational, personnel, information, technical and production [1]. These dimensions can be considered in the strict sense, but they will often be given an extended context. Dimensions are used as examples: economic and social, organizational and legal, production and logistics. All these dimensions, as well as their modifications, constitute a reference platform for management systems and processes shaping operational no tactivity and enterprise development. Generally widely understood development ability is a criterion for the enterprise assessment, which is a measure of projects implementing possibility at the high efficiency level. It expresses the ability to multiply assets and create progress in various fields of technological innovation activity in the context of enterprise development. Micro, small and medium-sized science and technology enterprises have become the important force to promote technological innovation and economical and social development [2].

One of an enterprise evaluation field is technological resources level. Products and processes require a number of technologies for its acquisition or realization. They may be of a key, while others are secondary. Technologies are characterized by the fact that they may be subject to minor changes over the decades, but they can also vary significantly in a short time $[3,16]$.

\footnotetext{
${ }^{*}$ Corresponding author: renata.stasiak-betlejewska@wz.pcz.pl
} 
Technology portfolio include technologies needed to produce the product. Currently, effective technologies that require less time and costs for production, installation and use are gaining greater significance [4]. Innovative technologies included in the portfolio allow faster and more reliable manufacturing process that guarantees a high quality product obtaining. Technology portfolio contributes also to the production processes modernization. Technologies, depending on the level of their advancement, may in a different way affect the competitive advantage of the company. There are basic types of technological strategies used in micro, small and medium - sized enterprises [5, 6]:

1. Uniqueness - offering something that nobody else can offer.

2. Complexity - the difficulty of learning the technology.

3. Quick imitation of technology (the basic product, process).

4. Robust construction - the basic model of the product or process has a long life cycle.

5. Changing the rules of competition - changing the competitive rules of the game.

6. Continuous introducing of the technological innovation (product, process).

7. Niche-specialized know-how.

8. Binding of a major customer - the customer adoption of technological strategies.

The technology interdependence within the portfolio can decide on its choice. If there is not established interrelation between seemingly separate technologies, technological „,bottleneck" can be a barrier in the product development [3]. The bottleneck is a vital element to the process realization, which despite the fact that it is used in $100 \%$ does not ensure maximum production $[7,9]$. Therefore one should pay attention to the fact that the advancement in technology one can be inhibited by limitations occurring in the other. Proper selection of technology has a huge impact on the final product quality.

The object of the enterprise analysis in the context of its development is the technological resources evaluation with using $\mathrm{ABC}$ technology method aimed on selection of the micro-enterprise technological development direction [10-12].

\section{Characteristics of the analysed micro-enterprise}

The study object was a micro - enterprise called Drewdom operates in the Silesian province and it employs: designer, two editors and two production workers. It deals with the production of the kitchen furniture in accordance to own or commissioned projects. The product offer includes a wide range of non-upholstered furniture such as: kitchen furniture, chests of drawers, wardrobes, desks, tables, tables, chairs. The analysed enterprise was founded in 1985. Due to the market completion intensification in 2009, there was noted orders decrease in Drewdom, which prompted the enterprise owner to take actions to improve the activity aimed at kitchen furniture production and starting the design activity of manufactured products. Technological equipment park of the enterprise consists: multispindle drilling machine, upper spindle milling machine, edge banding machine, format saw and machine for cutting holes for hinges.

The subject of technological resources level evaluation is Felder FD 921 multi-spindle drilling machine for drilling holes for joints in solid wood and wood-based materials that has one drilling head. The machining can be carried out vertically and horizontally. Drilling from the bottom ensures that the working surface of the table is free of chips and the drilling depth is constant, which eliminates time-consuming adjustment when the thickness of the plate being drilled changes. Table 1 presents technical data for Felder FD 921 multispindle drilling machine. 
Table 1. Technical data of the Felder FD 921 multi-spindle drilling machine

\begin{tabular}{|l|l|}
\hline nominal power & $1,5 \mathrm{~kW}$ \\
\hline max. height of the work piece & $65 \mathrm{~mm}$ \\
\hline table dimensions & $900 \times 380 \mathrm{~mm}$ \\
\hline number of spindles & 21 \\
\hline spacing between spindles & $32 \mathrm{~mm}$ \\
\hline max. thickness element & $55 \mathrm{~mm}$ \\
\hline insertion depth & up to $300 \mathrm{~mm}$ \\
\hline compensation for drilling depth & up to $8 \mathrm{~mm}$ \\
\hline max. drilling depth & $70 \mathrm{~mm}$ \\
\hline spacing between extreme spindles & $640 \mathrm{~mm}$ \\
\hline weight & $320 \mathrm{~kg}$ \\
\hline number of pressure cylinders & 2 \\
\hline min. air pressure & $6-8 \mathrm{bar}$ \\
\hline
\end{tabular}

\section{Research results and discussion}

Modernity level of machine parts can be classified with using the $\mathrm{ABC}$ technology analysis to assess their value and usefulness for the company in the period considered. As a criterion of evaluation, a competitive advantage may be used, expressed in the expensive leadership or in the product mix. The assortment's wealth can be achieved thanks to the flexibility of devices that allow the company to frequently change the type and quality of the product. The $\mathrm{ABC}$ analysis of the technology is based on the principle that each statistical group can be distinguished by several of its components (symbol A), which determine the main part of the results. At the other end of the distribution there are machine parts (symbol C) with a small contribution to the results of its activity [8, 10-15]. ABC analysis applies technology used to manufacture individual components in the machine and evaluate its modernity in a five-point scale Parker [10-13]:

1. Level 1 - simple parts that results from the craft techniques (e.g. a machine foundation).

2. Level 2 - parts based on unchanged and well - known technologies (e.g. standard engine cooling system).

3. Level 3 - parts produced by controlled technology, requiring appropriate technical knowledge (e.g. a standard electric motor).

4. Level 4 - parts that were produced using modern market technologies, e.g. displaying the diagnosis on the control panel computer.

5. Level 5 - parts resulting from the production of combined use of the state-of-the-art, patented technologies.

Results of the study affect decision on which machine parts should be upgraded or replaced. However, technologies are not isolated from each other, they often form constellations based on scientific principles. The basic subassembly consists of parts of category A, fundamental for the company's operations. They are also defined as elements implementing drive technologies, because they give special attributes (competitive advantage) to the product, such as a greater degree of surface smoothness. In this machine the primary component (Category A) is aimed at competitive advantage through its functions: control, input tools, programming, desktop support. The support sub-assembly (category B) is relevant to the drive system and the work piece handling system in the given case. Its role is to some extent dependent on the basic subassembly. The subassembly (category C) is associated with: the machine construction, foundation, energy supply and instrumentation. Parts of this subassembly are universal and, being used by any users, do not contribute to a competitive advantage. This does not mean that you can ignore them. 
The ABC method has been carried out for multi-spindle drilling machines Felder FD921. Thanks to this method, the modernity degree of the machine and its individual components taking part in the production process can be determined in order to identify parts that require modernization. Table 2 presents technical characteristics of the analyzed machine.

Table 2. Technical characteristics of the machine

\begin{tabular}{|l|l|}
\hline The machine element & Key technological aspects \\
\hline Construction & $\begin{array}{l}\text { steel table, on which the plate is placed which will be } \\
\text { processed, after placing it is pressed and the spindles } \\
\text { are drilled holes, stable side gears }\end{array}$ \\
\hline Foundation & Rubber foot for machines \\
\hline Energy supply system & $\begin{array}{l}\text { Engines, starters, on/off switch, spindle inclination } \\
\text { angle and drilling depth, compressor }\end{array}$ \\
\hline Drive system & $\begin{array}{l}\text { 2 hp }(1.5 \mathrm{~kW}) \text { engine with stable side gears, range and } \\
\text { variability of drilling speed }\end{array}$ \\
\hline Control system & $\begin{array}{l}\text { Dialogue with operator, level of precision, safety } \\
\text { limits }\end{array}$ \\
\hline Instrumentation & $\begin{array}{l}\text { The drill consists of } 21 \text { spindles that rotate one } \\
\text { clockwise to the other, at an angle that has been set }\end{array}$ \\
\hline $\begin{array}{l}\text { The operating system } \\
\text { of the work piece }\end{array}$ & $\begin{array}{l}\text { Positioning, pneumatic clamping, spindles, side } \\
\text { restrictions }\end{array}$ \\
\hline $\begin{array}{l}\text { System of support } \\
\text { functions }\end{array}$ & $\begin{array}{l}\text { The compressor that cools the motor and discharges } \\
\text { chips }\end{array}$ \\
\hline
\end{tabular}

The most important machine elements are listed in Table 2. The machine elements include: construction, foundation, energy supply system, instrumentation, operating system of the work piece, support function. In addition, key technological aspects are described.

Table 3 presents the evaluation of the machine parts modernity level for a multi-spindle drilling machine.

Table 3. Evaluation of the level of modernity of a multi-spindle drilling machine

\begin{tabular}{|c|c|l|c|}
\hline Subassembly & Symbol & \multicolumn{1}{|c|}{ Part / Element of the machine } & The modernity level \\
\hline \multirow{4}{*}{ A } & A1 & Control system & 3 \\
\cline { 2 - 4 } & A2 & Measuring system & 3 \\
\cline { 2 - 4 } & A3 & Drill head & 3 \\
\cline { 2 - 4 } & A4 & Nominal power & 3 \\
\cline { 2 - 4 } & A5 & Transmission feeds & 2 \\
\hline \multirow{4}{*}{ B } & B1 & Drive system & 2 \\
\cline { 2 - 4 } & B2 & Support & 2 \\
\cline { 2 - 4 } & B3 & Handles & 3 \\
\cline { 2 - 4 } & B4 & Pneumatic system & 3 \\
\cline { 2 - 4 } & B5 & Clamp cylinders & 3 \\
\cline { 2 - 4 } & B6 & Attaching the workpiece & 2 \\
\cline { 2 - 4 } & B7 & Foundation & 2 \\
\hline \multirow{4}{*}{ C } & C1 & Guideways & 3 \\
\cline { 2 - 4 } & C2 & Lubrication system & 2 \\
\cline { 2 - 4 } & C3 & Chip conveyor & 2 \\
\cline { 2 - 4 } & C4 & Board & 3 \\
\cline { 2 - 4 } & C5 & Regulating valve & \\
\hline
\end{tabular}


Parts and components included in the drilling machine are presented in Table 3. Each of the analyzed machine components has been evaluated in terms of the modernity level. They are divided into three groups A, B and C. The first group are the parts responsible for the quality of the product that will be processed. The second support group contains the most important parts of the machine that determine its usefulness. The third group is responsible for safety within using the device. Research results of the evaluation of the machine parts modernity level for a multi-spindle drilling machine are presented in Figure 1.

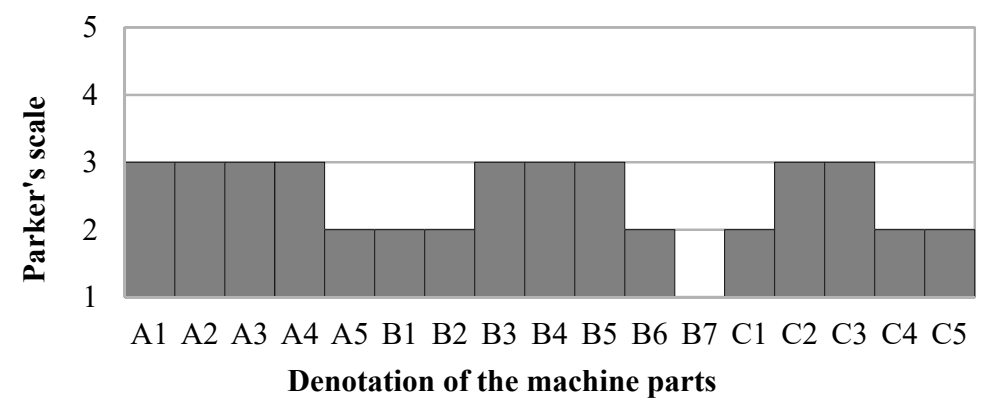

Fig. 1. Evaluation of the level of modernity of a multi-spindle drilling machine.

Data presented in Figure 1 show the research results of the machine parts modernity level analysis. The grades' average of the results for each subassembly group is following:

1. Category A: 2.8

2. Category B: 2.29

3. Category C: 2.4

The multi-spindle drill was evaluated according to the Parker scale $(1 \div 5)$. The highest number of the highest grades (3) were granted in the case of the individual introduction of new technological solution based on own development of elements in the category A. Thanks to this, product obtained owing to this subassembly can be adapted to individual customer's needs. The highest grade (5) was not received. Grade 4 could be obtained for new applications. Also in this category the grade 4 was not granted. Grade 3 was is the most common evaluation level. The evaluation could be obtained for technology that already exists and is already known, but it is not obsolete. The grade 2 was obtained 7 times, which is the second most common grade that was awarded for obsolete technology.

Rating 1 has been given only for 1 element, which means that it is already an old technique (no new elements have been introduced). The rating was assigned only once. Thus, in subassembly group A received an average score of 2.8 the most common grade 3 . In contrast, categories $\mathrm{B}$ and $\mathrm{C}$ show the greatest variation in assessments. The average rating for category $\mathrm{B}$ is at the level of 2.29 and category $\mathrm{C}$ at the average level of 2.4.

\section{Conclusions}

The object of the paper is technological resources analysis in the context of selection of the micro-enterprise development direction aimed at gaining the furniture product quality improvement. ABC technology method was applied to identify technological modernity level of the selected machine.

The analysed enterprise case confirms that applying of ABC technology method allows identifying modernity level of technological resources in the analyzed micro-enterprise what is one of the basic elements of decision process on the enterprise development. Presented research results allows identifying technological development direction for the 
analysed enterprise. It doesn't create additional costs and it can be effective tool for the eavluation of technological resources.

In the case of the analzyed micro - enterprise decision on the machine modernization with regard to the analzyed machine is connected with replacing individual elements that are responsible for the high quality of the product. Proposed solution should improve the machine's operation and increase its modernity level that affects the final product quality. The modern machine components will reduce the number of nonconformities, which will have a direct impact on the higher efficiency of the entire production process and lower costs associated with waste. Implementing advanced technology in the production equipment can affect the the competitive advantage of the company what result from implementing technological innovation strategy.

Acknowledgements. This work is related to the scientific program of the „Improving quality of processes, products and services" BW 615/201/07 supported by Polish Ministry of Science and Higher Education.

\section{References}

1. D.R. Gnyawali, D.S. Fogel, E.T. \& P., 43-62 (1994)

2. X. Fan, YZ. Huang, 3rd International Conference on Education and Education Research (Kuala Lumpur, Malaysia, 45-49, 2017)

3. P. Lowe, Management of Technology: Perception and Opportunities (Chapman \& Hall, London, 1995)

4. S. Kildiene, E.K. Zavadskas, J. Tamosaitiene, J. C. E. \& M., 20, 280-290, (2014)

5. H. Mizgajska, Aktywność innowacyjna polskich małych, średnich przedsiębiorstw w procesie integracji z Unia Europejska (Wydawnictwo AE, Poznań, 2002).

6. M. Gancarzyk, J. Gancarzyk, E. M. J., 36, 59-70 (2018)

7. R. Ulewicz, D. Jelonek, M. Mazur, Management and Production Engineering Review, 7, 89-94 (2016)

8. R. Stasiak-Betlejewska, R. Ulewicz, International Conference on the Path Forward for Wood Products: A Global Perspective (Baton Rouge, LA, USA, 149-156, 2016)

9. A. Maszke, Production Engineering Archives, 17, 45-48 (2017)

10. S. Borkowski S., J. Selejdak, Sz. Salamon, Efektywność eksploatacji maszyn i urzadzeń (Wyd.Wydziału Zarządzania Politechniki Częstochowskiej, Częstochowa, 2006)

11. S. Borkowski, R. Ulewicz, Instruments of production processes improvement, (PTM, Warszawa, 2009)

12. M. Ingaldi, Independent Journal of Management \& Production., 5(4), 993-1003 (2014)

13. A. Pilkington, T. Teichert, Technovation, 26, 288-299 (2006)

14. J. Pietraszek, E. Skrzypczak-Pietraszek, Adv. Mat. Res.-Switz., 874, 151 (2014)

15. K. Halicka, Technological and Economic Development of Economy, 22, 4, 574-597, (2016)

16. R. Ulewicz, M. Nowicka-Skowron, $26^{\text {th }}$ International Conference on Metallurgy And Materials, 2338-2343 (2017) 